\title{
Pengaruh Pembiayaan Syariah Terhadap Kinerja Keuangan Perbankan Syariah
}

\section{Siti Masitoh, Rachma Zannati*}

Fakultas Ekonomi dan Bisnis Universitas Islam Attahiriyah,

*Sekolah Tinggi Ilmu Ekonomi Indonesia, Jakarta, Indonesia

\section{Research Paper \\ Shariah Accounting}

Received: 11 Feb 2021

Accepted: 30 Mar 2021

Online : 09 Apr 2021

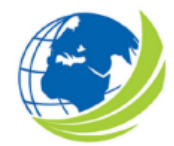

Keywords:

Mudharabah, Murabahah, Financing to Deposit Ratio, Non Performing Financing and Profitability.

\section{Corresponding Author:}

Rachma Zannati

Sekolah Tinggi Ilmu Ekonomi Indonesia, Jakarta

Email: rachmaznt@gmail.com

(C) The Author(s) 2021

DOI: https://doi.org/10.36407/akurasi.v3i1.324
Akurasi: Jurnal Riset Akuntansi dan Keuangan, Vol 3, No.1, 2021, pp. $43-57$

eISSN 2685-2888

\section{(C) (i)}

CC BY: This license allows reusers to distribute, remix, adapt, and build upon the material in any medium or format, so long as attribution is given to the creator. The license allows for commercial use. 